\title{
Management Development Programmes And Employee Performance In County Governments Of Kenya; A Case Of Narok County
}

\author{
Kimorgo Naeku Queen, Peter Paul Kithae, and Jane Mutua
}

\begin{abstract}
This paper aimed at exploring the role of management development programs on employee performance at the County Government of Narok, The study was guided by the following Research objectives: to determine the role of team building on employee performance at Narok County Government and, to ascertain how management conflict affect employee performance at Narok County Government. The study adopted a descriptive research design. The population under study was 1200 members of the Narok county staff. Data was collected from a sample size of 65 using both open and closed ended questions. Findings of the study were presented using tables and figures. Among the study findings were that team building was found to have a major role on the employee performance in Narok County and that it is a critical factor in enhancing employee performance. Likewise, conflict management was found to have contributed immensely in extending workers operating attitudes, productivity at work, and enhancing workers satisfaction. Finally, the paper recommends that there is need for a longtime team building programs targeting all cadres of staff upon employment, and that employees should undergo conflict management to enhance employees' working attitudes, to increase employees' productivity at work and to contribute to employees overall satisfaction.
\end{abstract}

Index Terms - Management Development Programs, Narok County Government, Employee performance.

\section{INTRODUCTION AND RESEARCH OBJECTIVES}

Management Development programs may be defined as a systematic development of knowledge, skills and behavior required by employees to do adequately a confirmed task or job or simply learning that is provided in order to improve performance on the present job (Amin et al., 2013) On the other hand, Elnaga and Imra (2013) defined Management Development programs as activities that provide workers with information, new skills, or professional development opportunities. According to Amin et al., (2013), business conditions change occasionally, calling for constant updating of employee aptitudes and capacities to enhance their activity execution, development and the capacity to adjust quickly to the changing financial situations for the association to stay focused.

To further delve into the focus of an entity, representative execution is of significant importance. This is the activity related exercise expected of an Employee and how well it is executed. Numerous business Human Resource executives

Published on November 6, 2019.

Kimorgo Naeku Queen, Management University of Africa, Kenya.

Peter Paul Kithae, Research Development and Innovations, Management University of Africa, Kenya. value the execution of every employee. According to McCormick Center (2015), an administration improvement program encourages the refreshing of aptitudes and prompt increment in responsibility, prosperity, and a feeling of belonging to a place. The essential part of Management Development programs is to enhance the workers' ability for present and future obligations and duties.

This Research paper's general objective is to look at the role of Management Development programs on employee performance at the Narok County Government.

Narok County is among the forty seven counties created by the Constitution of Kenya, 2010. It is situated in the Great Rift Valley. It is named after, Enkare Narok, the river running through Narok town. It constitutes six sub-counties, which are: Kilgoris, Narok North, Narok South, Narok East, Narok West and Emurua Dikirr. Narok County is a cosmopolitan county with the Maasai and Kalenjin considered as the dominant groups. The Maasai Mara Park, the Wilde beast home, is located 70 kilometers from Narok town. Narok Town is the headquarters of Narok County.

\section{A. Statement of the Problem}

According to files and records in the County registry, there are complaints from the narok residents over many enquiries which go for days without being addressed, and sometimes files not able to be traced for days. This implies that many officers in the county are not performing as is required and who therefore require the initialization of the management development programmes for better delivery of essential services. As the morale continues to decline, the need for more cost effective and coordinated management development programmes deepens throughout the Narok County Government Public Service. According to Du Plessis, Fouché and Van Wyk (2002), a talented force is a necessary demand for the expansion of any organization. There is therefore a tremendous need for coordinated and accessible management development programmes for all levels of officers in the Narok County Government.

\section{B. Research Objectives}

The overall aim of this research was therefore to provide an overview of the role of management development programmes on employee performance in the Narok County Government while specific objectives were to determine the

(e-mail: pkithae@mua.ac.ke).

Jane Mutua, Lecturer, School of Management and Leadership Management University of Africa, Nairobi, Kenya. 
role of team building on employee performance at Narok County Government and, to ascertain how management affect employee performance at Narok County Government conflict.

\section{Significant of the study}

The findings of the study are expected to help the government of Kenya and other stake holders to formulate good policies which can result to enhanced employee performance in all county governments in the country. Secondly, the county government of Narok will be enabled to develop and implement best programs for the county progress. Finally, the study findings will enrich existing theories for use by other researchers and academicians in disseminating knowledge to the journal again.

\section{THEORETICAL BACKGROUND AND INFORMING LITERATURE REVIEW}

Contingency theory of management affirms that when administrators settle on a choice, they should consider all parts of the present circumstance and follow up on those viewpoints that are critical to the current circumstance. Contingency theory suggests that management development programmes, standards and practices are reliant on situational fittingness.

Luthans (1976) takes note that "The customary ways to deal with administration were not really wrong, but rather today they are never again satisfactory". This theory promotes county government and other organisations to enhance their leadership and decision-making skills and provides options to the employees that help them to grow and share their ideas to the organization. On the other hand, the theory of performance improvement propounded by Vadivelu \& Klein,( 2008) states that any human resource development initiatives must be tied to the organization's strategic objectives as a method for improving performance. It builds on the social learning theory.

This theory is related to the work of Vadivelu \& Klein, (2008) on human competence who noted that human competence is a function of worthy performance; that human competence is inversely proportional to the potential for improving performance; that for any accomplishment, a deficiency in performance always has, as its immediate cause, a deficiency in behavior and that human accomplishments can be viewed at several levels of the organization. It is therefore essential for Narok County Government not to put targets to attain improvement but to put the fulfillments of these targets to reach a better performance. Finally, the chaos theory entails giving employees substantial freedom to do what they feel is right. Employees get total control of the decision making process. It is situational depending on what kind of institutional activity is using it. Most employers use and apply this theory successfully in their institutions or companies. Management development programmes in the Narok county Government are completely run in the various departments. Managers have limited responsibility because most decisions are done by employees. Managers' biggest responsibilities are directing.
As organizations consume more vitality, they look for more structure to look after strength. This pattern proceeds until the point that the framework parts, consolidates with another perplexing framework or goes into disrepair altogether. This trend is what many see as the trend in life, in organizations and the world in general (Bryson, 2014).

\section{A. Empirical Literature Review}

The empirical study of literature is an interdisciplinary field of research which incorporates the science, sociology, Philosophy, the contextual study of literature, and also the history of reading literary texts. The main purpose of management development programmes is to eliminate performance discrepancies whether current or anticipated. A study by Moran, Barbara B. (2013) in Management and Administration/General article indicated that Management development programmes leads to increased employee motivation. Management development programs also enhance competitive advantage of an organization. It is the core of competitive strategy.

According to a study by Gellatily,(2013), management development programmes encompass those capabilities, resources, relationships and decisions which permit an organization to capitalize on opportunities in the market place and avoid threats to its desired position. Management development programmes involve managers and subordinates put together establishing and clarifying workers 'goals. It roles execution through affecting what individuals think and do by centering their conduct toward objectives, invigorate conduct, spur individuals to advance the push to achieve troublesome objectives that are normal and illuminates obligations and duties. A study by Armstrong (2013) indicated that clear execution desires are a basic factor in cooperation achievement, regardless of whether the objective is to build up an undertaking group, a departmental group, or a feeling of collaboration vast, clear execution desires bolster cooperation achievement. Utilizing clear execution desires to enable representatives to create responsible, beneficial, important, participatory collaboration.

A study by Prasetya and Kato (2011) asserts that group building is characterized as the achieved result of activities with the abilities of workers who perform in some circumstances. A representative group is an accumulation of people who are related in the errands and who share obligation regarding the results. Groups empower individuals to collaborate, upgrade singular aptitudes and give productive input with no contention between people. Collaboration is an essential factor for smooth working of an association.

\section{Critique of the existing literature and research gaps.}

In the literature reviewed there is dominance of studies on the role of management development programs on employee performance in many areas but there is no study focusing on Narok County Government ,hence research in this line would add value to the literature in the area of study. There is need of further research in management development programmes on employee performance in the Narok County Government to find the dominating basis of employee performance. Despite the obvious benefits of management Development 
Programmes, research findings indicate that the programmes have not been embraced fully

\section{Conceptual Framework:}

A conceptual framework is an analytical tool with several variations and contexts. It provides an outline of how one plan to conduct the research for the study, but it goes further than that by also positioning the work done within the larger field of research. The Use of a conceptual Framework as a guide in a research study is very important. The framework plays an important role in guiding the entire process of the research study.

Management development programmes are the independent variable. Management development programmes variable is measured by the variables team building and conflict management. According to Elena.P (2010) when employees are self-directed, they develop a positive attitude towards their work and indeed would lead to employee performance .Employee Performance means employee productivity and output. Employee performance leads to high productivity, effective performance and low wastage of resources. Figure 1 shows the relationship between dependent and independent variables as conceptualized by the study.

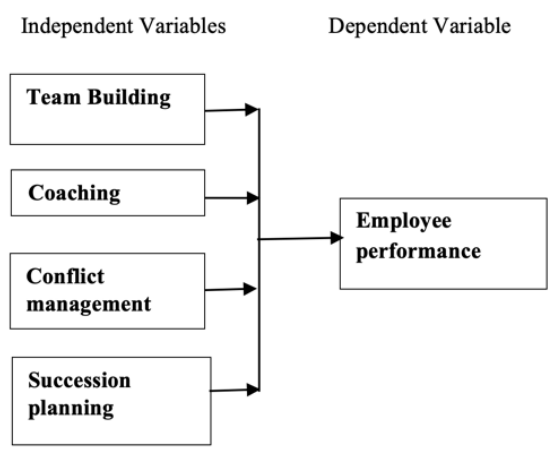

Fig. 1. Conceptual Framework

\section{RESEARCH METHODOLOGY}

This research utilized a descriptive research design. The target population under study was 1200 staff. Stratified random sampling technique was used to obtain a sample size of 85 employees who were categorized into various levels of management positions. According to Auka et al. (2013), stratified sampling ensures that each stratum is adequately represented and this facilitates comparison among the strata. As a rule of thumb, for a population less than 1000, a sample of $5 \%$ is sufficient in representing the entire population (Blanche, Durrheim\& Painter, 2008).

Primary data was gathered by use of questionnaires as Orodho (2005) asserts that questionnaires are the most preferred for primary data collection as they can gather data over a large sample. Collected data was classified according to the properties that characterized each of them, tabulated and analyzed using statistical package for social sciences (SPSS) for purposes of clarity. The study findings were then presented descriptively by use of tables and figures.

\section{RESEARCH FINDINGS AND DISCUSSIONS}

The purpose of the study was to assess the role of management development programmes on employee performance in Narok County Government of Kenya. The study was guided by the following research objectives: to assess the role of team building on employee performance at the Narok County Government and to establish the role of conflict management on employee performance at the Narok County Government of Kenya.

\section{A. Response Rate}

Out of the eighty five (85) questionnaires distributed, sixty five (65) were received back which amounts to $79.2 \%$ response rate which is quiet good for generalization to the whole target population of the study. This is in line with Awino (2011) recommendation that a response rate of 65 per cent is acceptable for social studies.

The study sought to get background information of the respondents to produce the foundation and inspiration of any study according to Gall et al., (2007). These demographic characteristics consisted of gender, cadre, age, highest skilled qualification and length or duration of service within the Narok County Government. In this regard, slightly over half of the respondents $(53.8 \%)$ who participated in the study were female while $(46.2 \%)$ were male. The perception of both gender in the study was important and the study met the $1 / 3$ gender rule as directed in Kenya (Kenyan Constitution, 2010).

\section{B. Findings on the Bio Data}

On the respondent's cadre, majority of the respondents (69.2\%) who participated in the study were the middle level (operational staff) and (30.8\%) were top level management. This shows that majority of the employees are operational staff. On the other hand, the age bracket of the respondents studied revealed that majority $(73.9 \%)$ were below 40 years. Almost an equal number (13.8\%) and (12.3\%) were between 41-50 years and 51years and above respectively. This was in line with recommendations that the target age distribution for the study should be represented to ensure an all-inclusive and authentic study (Rubin, 2012). The study therefore met this threshold. On professional qualification of the respondents, the study revealed that majority of the respondents $(46.2 \%)$ had a bachelor's degree, (33.8\%) had diploma, (10.8\%) had certificate, while $(9.2 \%)$ had a master's degree and above. Assessing the academic levels of respondents in a study was deemed necessary as it indicated the level of professionalism and authenticity of the data obtained from the respondents (Aaker \& Day, 2015).

Duration of respondents in the organization was studied and the findings revealed that slightly over half of the respondents $(52.3 \%)$ had worked for 10 years and below while $(47.7 \%)$ had been in the organization for 11 years and above. This was important since the experience was necessary on feedback received, according to Matern, V. (2013). 


\section{Findings on the research objectives}

\section{Effect of team building on employee performance in county governments of Kenya}

According to the study objectives, the study sought to assess the role of team building on employee performance at Narok County. This section investigated whether the respondents had undergone team building, extent to which team building contributes to employee commitment and whether team building had a positive effect on employee performance. From responses, minority (49.2\%) of the respondents indicated that they had attended team building while majority $(50.8 \%)$ had not attended team building since they joined Narok County Government. This shows that team building is not conducted on all employees in the County Government. On team building's contribution to employee commitment to the County Government, majority of respondents $(95.4 \%)$ indicated that team building contributes immensely to increased employee commitment while only $4.6 \%$ stated that team building does not increase employee commitment. This shows that employees believe they can be more committed to the organization when engaged in team building in the organization. Likewise, an overwhelming majority $(92.3 \%)$ of respondents indicated that team building contributes to a positive impact on employee's performance within the Narok County. Among some positive effects of team building mentioned included introduction to organization culture, workers and customers, structure and therefore the employee's future tasks.

On the role of team building on employee's performance, responses from respondents were as in Table I.

TABLE I: EFFECT OF TEAM BUILDING ON EMPLOYEE PERFORMANCE

\begin{tabular}{llllll}
\hline Statement & $\begin{array}{l}\text { Srongly } \\
\text { Agree }\end{array}$ & Agree & $\begin{array}{l}\text { Not } \\
\text { Sure }\end{array}$ & Disagree & $\begin{array}{l}\text { Strongly } \\
\text { Disagree }\end{array}$ \\
\hline $\begin{array}{l}\text { Team building } \\
\text { reduces } \\
\text { employee's } \\
\text { turnover }\end{array}$ & $16.9 \%$ & $27.7 \%$ & $27.7 \%$ & $20.0 \%$ & $6.2 \%$ \\
$\begin{array}{l}\text { Team } \\
\text { building cost } \\
\text { reduction } \\
\text { process }\end{array}$ & $29.2 \%$ & & & & \\
& & $32.3 \%$ & & & \\
$\begin{array}{l}\text { Team } \\
\text { building has } \\
\text { positive } \\
\text { effect } \\
\text { employee } \\
\text { attitude and } \\
\text { behavior }\end{array}$ & $52.3 \%$ & $43.1 \%$ & $1.5 \%$ & $1.5 \%$ & $1.5 \%$ \\
\end{tabular}

From Table I, Majority of the respondents (44.6\%) either strongly agreed or was in agreement that correct team building reduces turnover rate whereas $(26.2 \%)$ disagreed. However, $(27.7 \%)$ were not sure whether or not team building reduces turnover rate on whether or not team building results in value reduction within the work processes $(61.5 \%)$ of the respondents were either strongly in agreement or in agreement whereas $(13.9 \%)$ disagreed or strongly disagreed to the statement, $(23 \%)$ were not sure whether or not team building leads to value reduction in work processes. An overwhelming majority of the respondents (95.4\%) either strongly agreed or were in agreement that team building has a positive impact on employee's attitude and behavior; and only $(3 \%)$ either disagreed or powerfully disagreed. However $(1.5 \%)$ were not certain whether or not team building includes a positive impact on workers perspective and behavior. Finally, (93.8\%) of the respondents were either strongly in agreement or in agreement that team building introduces the worker to the organization and different workers within the organization against $(4.6 \%)$ respondent who either disagreed or powerfully disagreed. Only $(1.5 \%)$ were not certain whether or not team building introduces the worker to the organization and different workers within the organization.

In summary, this study found team building to be a critical element of management development programmes that roles employee performance.(95.4\%) and (93.8\%) of the respondents respectively indicated that team building has a positive effect on employee's attitude and behavior and introduces the employee to the organization. The findings align to a study by Mullins,(2012) that found out that team building introduces new employees to the culture and environment of the organization, its policies and practices and to other members of staff. Foot and Hook (2008) further observe that team building helps new employees to settle quickly into their job to become efficient and productive. This is as per the findings of this study whereby the respondents indicated that team building had a positive impact on employee's perspective and behavior and introduces the worker to the organization. Over $1 / 2$ the respondent $(50.8 \%)$ had not undergone any team building. but most workers had undergone a team building program.

\section{Role of conflict management on employee performance}

The study sought to establish the role of conflict management on employee performance at Narok County Government. The information sought included whether respondents had undergone any conflict management, the extent to which conflict management contributed towards employee performance, extent to which it influenced performance in the organization and whether conflict management makes employees more productive at work. From the responses, majority (58.5\%) stated they had undergone conflict management after joining the Narok County while $41.5 \%$ had not undergone the program. On the effect of conflict management and working attitudes, majority of the respondent $(76.9 \%)$ indicated that conflict management led to enhanced working attitudes, (6.2\%) indicated that it doesn't result in increased operating attitudes whereas $(16.9 \%)$ were not sure. This shows that over half the workers praised the role of conflict management as enhancing working attitude within the Narok County Government. On the role of conflict management on employee performance, majority of the respondents $(63.1 \%)$ indicated that conflict management increases employee performance either to some extent or to a greater extent while (13.8\%) were not sure, $(3.1 \%)$ did not know and $(6.2 \%)$ refuted the statement. This shows that employees of the Narok County are likely to be more productive to the organization when they undergo conflict management programmes. 
Role of conflict management on employee satisfaction at Narok County was assessed using indicators like employee's performance at work; their interaction, and worker retention resulted from worker satisfaction. Results from the findings indicated that an overwhelming majority (87.7\%) were strongly in agreement or in agreement that conflict management programmes reinforce employees' operating attitudes whereas a minimal variety $(12.3 \%)$ didn't agree. Once asked whether or not conflict management increase staff productivity at work, most respondents $(72.3 \%)$ were in agreement whereas $(24.6 \%)$ didn't agree. Finally, slightly over $(53.9 \%)$ of the respondents indicated that conflict management contributes to worker satisfaction completely as compared with $44.6 \%$ who did not affirm to the statement.

The study results indicate that majority of the respondents agreed that conflict management contributes to increase in employee productivity, contributes to employee satisfaction and enhances employee loyalty; and seem to be in line with Hanson (2008) and Ankita (2012) who asserted that conflict management leads to long term success in organizations

\section{CONCLUSIONS AND RECOMMENDATIONS}

\section{A. Conclusions}

Based on the research objectives, team building was found to have a major role on the employee performance in Narok County and that it is a critical factor in enhancing employee performance. All respondents indicated that team building had a positive role on employee attitude and behavior and positively affected performance. However, the program focused more on middle level employees and most employees had not attended the team building programs

Conflict management programmes are in kind of workshops and seminars lasting some days. Not all workers had undergone conflict management. The program had contributed to extend in worker operating attitudes, productivity at work, boosting of worker morale and absolutely effecting worker satisfaction.

\section{B. Response Rate}

There is need for a longtime team building program targeting all cadres of staff upon employment.

Employees should undergo conflict management programmes to enhance employees' working attitudes, increase employees' productivity at work and contribute to employee satisfaction positively. The County Government should ensure the program is planned and implemented.

\section{Areas for Further Studies}

This research looked at the role of management development programmes on employee performance in county governments of Kenya. It is suggested that further research be done on the effect of monitoring and evaluation on employee performance in county governments of Kenya.

\section{REFERENCES}

[1] Amin, A. et al. (2013). The Impact of Employees Training On the Job Performance In Education Sector of Pakistan. Middle-East Journal of Scientific Research 17 (9),

[2] Blanche, M. T., Durrheim, K. \& Painter, D. (Eds.) (2018). Research in Practice. Applied Methods for Social Sciences. Cape Town. University of Cape Town Press

[3] Bryson (2014) on chaos theory, the trend in life in organizations and the world.

[4] Du Plessis, Fouché and Van Wyk (2002), a talented force 1273-1278.

[5] Elena P. (2010). The relationship between job satisfaction and health: a meta- analysis. Occupational and Environmental Medicine.

[6] Elnaga, A. \& Imran, A. (2013). The Effect of Training on Employee Performance. European Journal of Business and Management, 5 (4), 137-147

[7] Garson, D. (2012). Sampling. Raleigh, NC: Statistical Associates Publishing

[8] Lazear \& Rosen, (2011) succession planning as an incentive tool

[9] Luthans (1976) Contingency theory, the customary ways to deal with administration.

[10] McCormick Center (2015) Quality Improvement in Program Administration through Directors' Support Cohorts

[11] Moran, Barbara B. (2013) Management and administration/general

[12] Prasetya and Kato (2011) Group building

[13] Shaheen, Naqvi \& Khan, (2013). Effect of Training Dimensions on Employee's Work Performance: A Case of Mumias Sugar Company in Kakamega County. International Journal of Business and Management Invention, 2(9), 138-149

[14] Vadivelu \& Klein, (2008) Theory of Performance Improvement on human competence

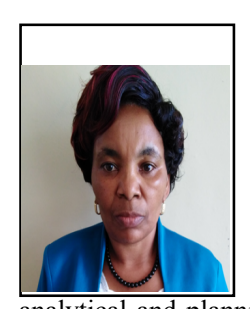

Queen Naeku Kimorgo is currently the Asst.Director Human Resource Management at the County Government of Narok. She is a highly experienced Human Resource and Public Administration Practitioner, with comprehensive and strategic understanding of the working of the Public Service with over 20 years' experience in the Service.

An excellent team player with good organization, analytical and planning skills. Good staff management skills, ability to build, lead and manage a team, motivate and inspire staff so that they work towards individual and organizational goals. She also has an indepth knowledge of how Government functions and their interrelationships as spelt out in the Constitution of Kenya, and other enabling Legislations. She is able to manage and prioritize a high workload and multiple tasks in a fast paced environment with strict deadlines.

She inculcates an entrepreneurial mindset in all she does. Taking pride in work and giving the best to each assignment.

Queen holds a Bachelor of Law(LLB) degree from the University of South Africa ,a Bachelor of Arts from Vision International University (USA)

and a Diploma in Human Resource Management from Cambridge Tutorial College, Britain.

Further research is to be done on the effect of monitoring and evaluation on employee performance in County governments of Kenya.

Ms. Kimorgo, is a member of the Institute of Human Resource Practitioners of Kenya (IHRM), and has previously and currently been rated as the Best senior Officer.

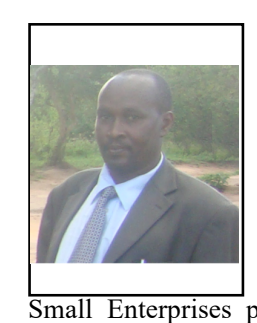

Peter Paul Kithae is currently the Director, Research, Development and Innovations of the Management University of Africa; the honorary treasurer for the Kenya Red cross Society, Upper Eastern Kenya Region and a Senior Consultant with the Total Quality Management firm of Consultants. Among Dr. Kithae's published work include a Print book on "Technology adoption and its effect on performance of Youth Led Micro and Small Enterprises printed in June, 2015, a paper on the Extent the government has shaped MSE's destiny towards achievement of Kenya's vision 2030; A paper on the Effect of quality improvement practices on micro and small enterprise performance and another on Unleashing Potentiality of Our Youth through Entrepreneurship Training: A Must for Realization of Kenya's Vision 2030 among others.

Dr. Kithae is a career civil servant who has successfully worked as a Chief Youth Officer for three years and later as a Principal Youth Officer for 
two years in charge of Youth Development services in Makueni and Kirinyaga counties respectively. He has attended a lot of seminars and workshops and has facilitated a number of them. Among these are project planning and management, performance contracting, capacity assessment training and disaster preparedness and response. He is a renowned educationist, having been a senior Lecturer at the Management University of Africa for over four years, a part time lecturer in various universities for over five years and a lecturer of Entrepreneurship, management and Business Studies in various tertiary institutions for over 18 years. Dr. Kithae has also been a Senior Examiner and Team leader for Business Studies with the Kenya National Examinations Council for over 10 years and a Senior Examiner for Research methods with the Kenya Institute of Management for over five years.and a Diploma in Human Resource Management from Cambridge Tutorial College, Britain.

Further research is to be done on the effect of monitoring and evaluation on employee performance in County governments of Kenya.

Ms. Kimorgo, is a member of the Institute of Human Resource Practitioners of Kenya (IHRM), and has previously and currently been rated as the Best senior Officer. 